\title{
Regulatory role of tet $R$ gene in a novel gene cluster of Acidovorax avenae subsp. avenae RS-1 under oxidative
}

\section{stress}

\author{
He Liu ${ }^{1,2}$, Chun-Lan Yang ${ }^{1}$, Meng-Yu Ge ${ }^{1}$, Muhammad Ibrahim ${ }^{1,3}$, Bin Li ${ }^{1}$, Wen-Jun Zhao ${ }^{4}$, \\ Gong-You Chen ${ }^{5}$, Bo Zhu ${ }^{1}$ and Guan-Lin Xie ${ }^{\text {* }}$
}

' State Key Laboratory of Rice Biology, Institute of Biotechnology, Zhejiang University, Hangzhou, China

${ }^{2}$ Department of Plant Pathology, University of California Davis, Davis, CA, USA

${ }^{3}$ Department of Biosciences, COMSATS Institute of Information Technology, Sahiwal, Pakistan

${ }^{4}$ Chinese Academy of Inspection and Quarantine, Beijing, China

${ }^{5}$ School of Agriculture and Biology, Shanghai Jiao Tong University, Shanghai, China

\section{Edited by:}

Radhey S. Gupta, McMaster

University, Canada

\section{Reviewed by:}

Yuejin Hua, Zhejiang University, China Herb Schellhorn, McMaster

University, Canada

\section{${ }^{*}$ Correspondence:}

Guan-Lin Xie and Bo Zhu, State Key Laboratory of Rice Biology, Institute of Biotechnology, Zhejiang University, 310058 Hangzhou, China e-mail: glxie@zju.edu.cn; bzhu@zju.edu.cn
Acidovorax avenae subsp. avenae is the causal agent of bacterial brown stripe disease in rice. In this study, we characterized a novel horizontal transfer of a gene cluster, including tet $R$, on the chromosome of $A$. avenae subsp. avenae RS-1 by genome-wide analysis. TetR acted as a repressor in this gene cluster and the oxidative stress resistance was enhanced in tetR-deletion mutant strain. Electrophoretic mobility shift assay demonstrated that TetR regulator bound directly to the promoter of this gene cluster. Consistently, the results of quantitative real-time PCR also showed alterations in expression of associated genes. Moreover, the proteins affected by TetR under oxidative stress were revealed by comparing proteomic profiles of wild-type and mutant strains via 1D SDS-PAGE and LC-MS/MS analyses. Taken together, our results demonstrated that tet $R$ gene in this novel gene cluster contributed to cell survival under oxidative stress, and TetR protein played an important regulatory role in growth kinetics, biofilm-forming capability, superoxide dismutase and catalase activity, and oxide detoxicating ability.

Keywords: horizontal gene transfer, tetR, repressor, oxidative stress, EMSA, proteome profiling

\section{INTRODUCTION}

Acidovorax avenae subsp. avenae, (formerly Pseudomonas avenae) is a Gram-negative, rod-shaped causal bacterial agent, which infects many economically important crops, including rice, maize, millet, oats, sugarcane, and foxtail (Song et al., 2004). In rice, it causes bacterial brown stripe (BBS) disease, which is a devastating rice disease in some areas in Asia, Africa, North America, and Europe (Xie et al., 1998, 2011). Although this worldwide rice disease has caused significant yield and quality losses, currently little is known about this bacterial pathogen, especially at the molecular and cellular levels. Recently, the draft genome sequence of A. avenae subsp. avenae RS-1 has been released (Xie et al., 2011). This opens a new avenue to study this pathogen that will ultimately lead to better control of this disease.

Comparative genomic analysis with closely related species has revealed several novel horizontally transferred gene clusters in this pathogen (Xie et al., 2011). Horizontal gene transfer (HGT) is a progress in which an organism incorporates genetic material from other organisms without vertical inheritance. This progress has been considered as a major driving force in bacterial evolution (Ochman et al., 2000). HGT can transfer not only one gene to the recipient that enhances the niche adaption, but even an entire gene cluster that may dramatically alter the metabolic repertoire of the host, even creating functional novelties, including stress response (Slade and Radman, 2011).

Bacterial cells are always exposed to various adverse conditions and surroundings, which compel them to adapt to conditions far from optimum. For example, oxidative stress occurs when reactive oxygen species are naturally generated in aerobically growing cells where incomplete reduction of molecular oxygen happens during their normal metabolism. These toxic compounds induce oxidative stress to the cell, damaging nucleic acids, and proteins (Imlay, 2013). The reactive oxygen species include hydrogen peroxide $\left(\mathrm{H}_{2} \mathrm{O}_{2}\right)$, superoxide radical $\left(\mathrm{O}_{2} \cdot\right)$, and hydroxyl radical (HO-). Reactive oxygen species can also occur from a variety of environmental sources, such as redox-cycling agents and ionizing radiation (Sies, 1997). Paraquat, one kind of redox-cycling agents, can generate endogenous superoxide stress and react with respiratory chain components in bacterial cells (Tu et al., 2012). In most cases, survival in this unstable environment requires a wide range of adaptive, effective feedbacks mediated or triggered by regulatory proteins (Ramos et al., 2005). The TetR protein family is a common class of transcriptional regulator found in a diversity of bacteria. It has been reported that this protein family can take function in various physiological processes, such as biosynthesis of antibiotics and expression of enzymes implicated in catabolic pathways, and multidrug resistance (MDR; August et al., 1998; van der Geize et al., 2000; Cho et al., 2003; Rand et al., 2006). However, only about $5 \%$ among them have been fully characterized (Ramos et al., 2005; Hillerich and Westpheling, 2008), and fewer were reported in phytopathogens (Ramos et al., 2005).

Whole genome sequencing of the A. avenae subsp. avenae RS1 strain has provided a general view of HGT, which may have 
enhanced its pathogenicity or survival ability. In this study, we found a horizontally transferred gene cluster containing four genes including the tetR gene and paraquat-inducible genes ( $\left.p q i A A^{\prime} B\right)$. We investigated the role of TetR in regulating expression of this gene cluster and found it negatively regulated its expression. We also found TetR plays a role in cell growth rate, biofilm formation, and oxidative stress survival.

\section{MATERIALS AND METHODS \\ BACTERIA STRAINS, PLASMIDS, AND CULTURE CONDITIONS}

Strains and plasmids used in this study were listed in Table $\mathbf{1}$. A. avenae subsp. avenae strains were grown in Luria-Bertani (LB) broth or LB with $1.5 \%(\mathrm{w} / \mathrm{v})$ agar at $30^{\circ} \mathrm{C}$. LB agar without sucrose and LB agar containing $10 \%(\mathrm{w} / \mathrm{v})$ sucrose were used for deletion mutagenesis (Li etal., 2011). The bacterial optical density (OD600) was determined with a spectrophotometer (Perkin Elmer Lambda35 UV/VIS). When required, antibiotics were added at the following concentrations: ampicillin (Amp), $100 \mu \mathrm{g} \mathrm{ml}^{-1}$; chloromycetin (Chl), $3.4 \mu \mathrm{g} \mathrm{ml}^{-1}$; $\operatorname{kanamycin}(\mathrm{Km}), 50 \mu \mathrm{g} \mathrm{ml}^{-1}$; and rifampicin (Rif), $100 \mu \mathrm{g} \mathrm{ml}^{-1}$.

\section{PLANT MATERIAL AND INOCULATION FOR BACTERIAL VIRULENCE ASSAY}

The cultivar of rice plant used in this study was ZheYou\#1 (susceptible to A. avenae subsp. avenae). Experiments were performed in greenhouse. For inoculating plants, strains were grown in $\mathrm{LB}$ broth for $48 \mathrm{~h}$, diluted in $\mathrm{ddH}_{2} \mathrm{O}$, and adjusted to OD600 of $0.6\left(1 \times 10^{8} \mathrm{CFU} \mathrm{ml}^{-1}\right.$; Liu et al., 2012). Leaf-clip inoculation was carried out on 6 weeks-old rice plants. Lesion length was measured at 14 days post-inoculation (Yu et al., 2011).

\section{PHYLOGENETIC ANALYSIS}

Each gene of interest was compared against sequences in the NCBI nr database using BLASTp (Altschul etal., 1997) followed by extracting the sequence of each specie with highest similarity for further study. We considered two genes as homologs when E-value $<10^{-5}$ and when the alignment similarity was higher than $40 \%$ with more than $80 \%$ coverage (Nogueira et al., 2009). ClustalW was used for sequences alignment (Thompson et al., 1994), and the conserved region of each alignment was trimmed with Gblocks (Castresana, 2000) under stringent settings described previously (Ciccarelli et al., 2006).

Table 1 | Strains and plasmids used in this study.

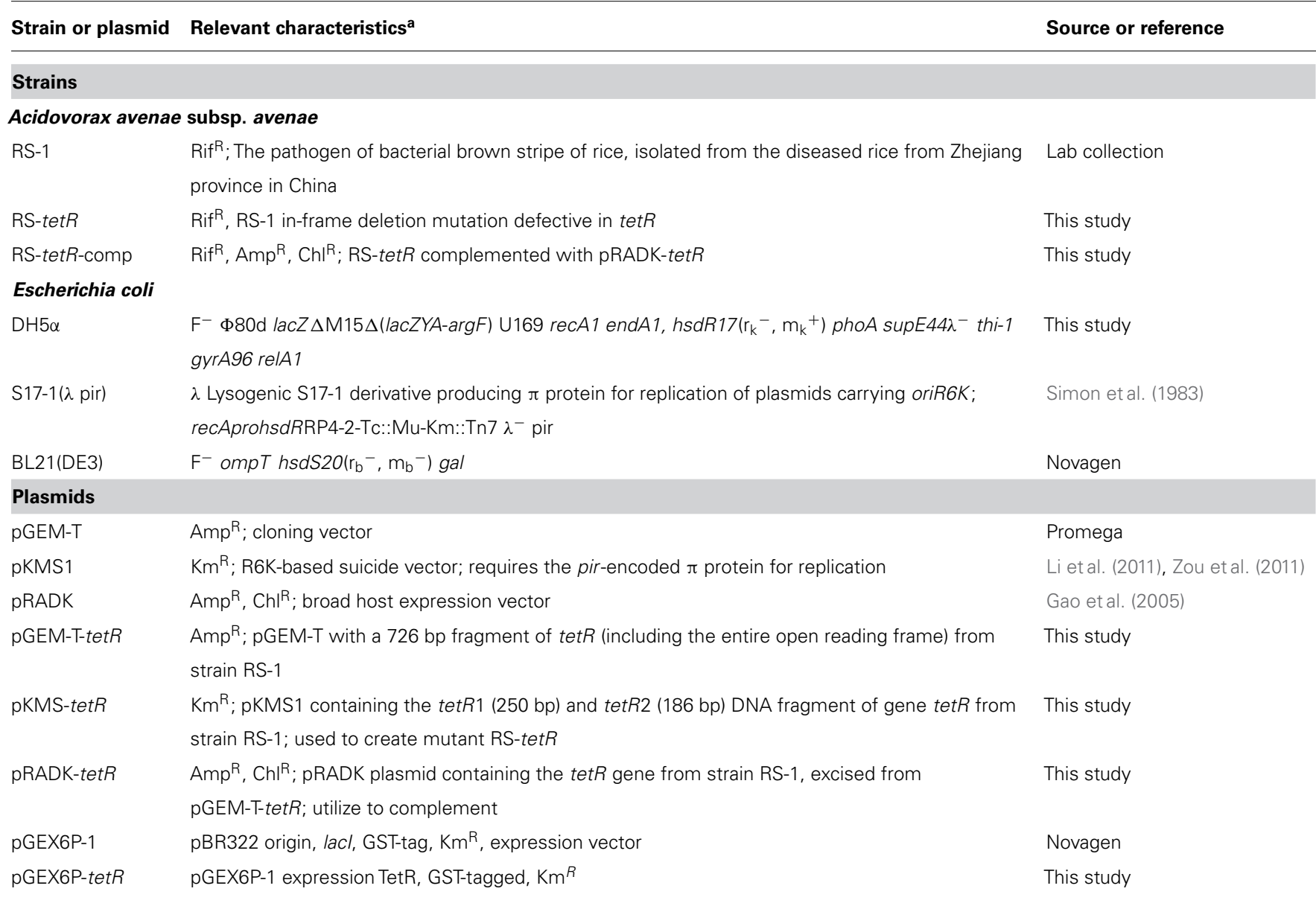

${ }^{a} A m p^{R}, C h l^{R}, K m^{R}, R i f^{R}$, indicate ampicillin-, chloromycetin-, kanamycin-, rifampicin-resistant, respectively. 
Maximum Likelihood (Fang et al., 1999) phylogenies were evaluated and built by PhyML (Guindon and Gascuel, 2003) using a JTT model and a gamma distribution with eight rate categories. We performed 1,000 bootstraps to gain branch support values.

\section{CONSTRUCTION OF tetR-DEFECTIVE DELETION MUTANT AND COMPLEMENTATION}

To investigate the role of tet $R$ in $A$. avenae subsp. avenae, an in-frame deletion mutation by double cross-over events of this gene (RS_1091) was constructed as described previously using the suicide vector pKMS1 (Li etal., 2011; Zou etal., 2011) by homologous recombination on the background of wild-type strain RS-1. Briefly, two fragments flanking the start and stop codons of target gene, tetR 1 (250 bp) and tetR2 (186 bp), were amplified from the wide-type genomic DNA (gDNA) with primer pairs tetR1$\mathrm{F} /$ tet $R 1-\mathrm{R}$ and tetR2-F/tetR2-R (Table $\mathrm{S} 1$ ), respectively. The two fragments were digested with BamHI and HindIII and ligated into the vector pKMS1 at the corresponding sites, resulting in pKMStetR. This recombinant plasmid was transferred into Escherichia coli S17-1 $\lambda$ pir (Simon et al., 1983) and then introduced into $A$. avenae subsp. avenae by filter mating (Smith and Guild, 1980). The single colonies that emerged on LB plates containing kanamycin and rifampicin at $30^{\circ} \mathrm{C}$ for 2 days were then transferred to $\mathrm{LB}$ broth medium followed by incubating at $30^{\circ} \mathrm{C}$ and $200 \mathrm{rpm}$ for $16 \mathrm{~h}$. Afterward, the bacterial culture was plated to LB agar containing $10 \%(\mathrm{w} / \mathrm{v})$ sucrose for the second cross-over through $\mathrm{sacB}$ and sucrose-positive selection. After sucrose resistant colonies were patched onto LB and LB plus kanamycin plates, respectively, individual colony that grew normally on LB plates, but did not grow on LB containing kanamycin, was considered potential deletion mutants where double exchange homologous recombination events occurred at the two tet $R$ fragments, resulting in a 267 bp deletion. One of the mutants, named RS-tetR, was subsequently verified by PCR and sequencing before using for further study.

In order to complement the RS-tetR strain, the $1062 \mathrm{bp}$ fragment containing full-length of tet $R$ gene and $300 \mathrm{bp}$ of its upstream region was amplified by PCR. The primers were designed based on RS-1 genome and listed in Table S1. The PCR product was cloned into pGEM-T Easy vector, verified by sequencing, and then cloned into pRADK (Gao et al., 2005). Complementation vector was introduced into mutant cells by electroporation and complementary strain was selected by resistance to Chl and Amp.

\section{GROWTH CURVE AND SURVIVAL ASSAYS}

In order to monitor the growth rate, the growth curve assays were performed as described by Tu et al. (2012) with minor modification. $1 \mathrm{ml}$ overnight culture, which was grown at $30^{\circ} \mathrm{C}$ with $200 \mathrm{rpm}$ agitation in LB broth, was added into $99 \mathrm{ml}$ fresh $\mathrm{LB}$ broth to OD600 of 0.05. The concentration of commercial $30 \% \mathrm{H}_{2} \mathrm{O}_{2}\left(10 \mathrm{~mol} \mathrm{~L}^{-1}\right)$ solution and $100 \mathrm{mmol} \mathrm{L}{ }^{-1}$ paraquat (N,N'-dimethyl-4,4'-bipyridinium dichloride, $\mathrm{C}_{12} \mathrm{H}_{14} \mathrm{Cl}_{2} \mathrm{~N}_{2}, 257.16 \mathrm{~g} \mathrm{~mol}^{-1}$ ) solution (2.57 $\mathrm{g}$ solid

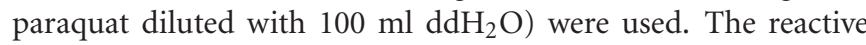
oxygen compound $\left(\mathrm{H}_{2} \mathrm{O}_{2}\right.$ or paraquat) was added at mid-log phase $(\mathrm{OD} 600=0.3)$ to the indicated final concentrations. After comparing with the untreated bacterial growth curve, the sensitivity and tolerance of cells to the reagents was determined. This experiment was repeated three times independently.

\section{PROTEIN PURIFICATION AND LC-MS/MS ANALYSIS}

Protein extraction was performed as described by Tu et al. (2012) with some modifications. Briefly, $2 \mathrm{ml}$ overnight grown cells were added to $100 \mathrm{ml}$ fresh $\mathrm{LB}$ broth to continue growing at $30^{\circ} \mathrm{C}$ with $200 \mathrm{rpm}$ agitation. Paraquat or $\mathrm{H}_{2} \mathrm{O}_{2}$ was added to cells at mid-log phase $(\mathrm{OD} 600=0.3)$ to the indicated concentration that perturbed the growth without causing cell death according to the survival assay (40/60 $\mathrm{mM} \mathrm{H}_{2} \mathrm{O}_{2}$ or $0.4 / 0.8 \mathrm{mM}$ paraquat, RS-1/RS-tet $R$ ). Cells were harvested by centrifugation $\left(5,000 \mathrm{~g}, 10 \mathrm{~min}, 4^{\circ} \mathrm{C}\right)$ after exposure to the oxidative compounds for $60 \mathrm{~min}$. Then the cells were treated with lysozyme $(1 \mathrm{mg} / \mathrm{mL})$ in the phosphate buffer ( $\mathrm{pH} 8.0$ ), disrupted by ultrasound, and centrifuged at $12,000 \mathrm{~g}$ for $15 \mathrm{~min}$ at $4^{\circ} \mathrm{C}$ in a Sorvall centrifuge to remove cell debris. A second-time centrifugation step $\left(20,000 \mathrm{~g}, 30 \mathrm{~min}, 4^{\circ} \mathrm{C}\right)$ was required by by Sorvall centrifuge (Sorvall WX100, Thermo Scientific, USA). The protein content was quantified using the enhanced BCA Protein Assay Kit (Beyotime, China).

Protein extracts were subject to 1D SDS-PAGE gel composed of $5 \%$ acrylamide for stacking gel and 10\% for running gel (Schägger and Von Jagow, 1987) with a mini-gel apparatus (VE-180 vertical electrophoresis bath, Tanon, China). Subsequently, the separated protein bands in the SDS-PAGE gel were visualized by silver staining.

The peptides released from trypsin digestion for LC-MS/MS analyzing were prepared in two biological replicates. LC was performed using a Dionex Ultimate 3000 nano-LC system. Firstly, the tryptic peptides were acidified by $2 \%$ acetonitrile with $0.025 \%$ trifluoroacetic acid before loading onto the Dionex Acclaim PepMap 100, C18 trap column $(20 \mathrm{~mm} \times 100 \mu \mathrm{m}, 5 \mu \mathrm{m}, 100 \AA)$ at the flow rate of $10 \mu \mathrm{l} \mathrm{min}{ }^{-1}$. Then, the Dionex Acclaim PepMap 100, C18 analytical column $(150 \mathrm{~mm} \times 75 \mu \mathrm{m}, 3 \mu \mathrm{m}, 100 \AA)$ were applied to divide the enriched tryptic peptides by gradient elution. The Bruker amaZon electron transfer reaction (ETD) ion trap system coupled with nano source expanded the capability to identify the trapped tryptic peptides under $300-1400 \mathrm{~m} / \mathrm{z}$ and $50-2200 \mathrm{~m} / \mathrm{z}$ scan range for MS and MS/MS, respectively.

The MASCOT LC-MS/MS ion search algorithm (Matrix Sciences) was applied to evaluate the LC/MS spectra and sequence similarity of resulting peptides to $A$. avenae subsp. avenae RS1 was compared with Acidovorax species accessible on NCBI. To further identify the proteins, the cross correlation scores (X corr; Lin et al., 2007) of singly-, doubly- and triply-charged peptides were fixed greater than 1.8, 2.5 and 3.5, respectively. Then, a list of peptide sequences with the highest $\mathrm{X}$ corr values was identified. The hydrophobic nature of proteins was accessed through evaluating the grand average of hydropathicity (GRAVY) score of peptides by ProtParam ExPASy. Furthermore, proteins were annotated by RAST automatic pipeline to analyze their function.

\section{ENZYME ASSAYS FOR SOD AND CATALASE}

After protein purification as mentioned above, $1-2.5 \mu \mathrm{g}$ protein was used to measure superoxide dismutase (SOD) or 
catalase activities. Precisely, SOD activity was determined with a SOD assay Kit-WST (Beyotime, China). The Catalase Assay Kit (Beyotime, China) was used to detect catalase activity. Briefly, for SOD activity assay, the samples were treated by WST-8 [2-(2-methoxy-4-nitrophenyl)-3-(4-nitrophenyl)-5-(2,4disulfophenyl)-2H-tetrazolium, monosodium salt] and incubated at $37^{\circ} \mathrm{C}$ for $30 \mathrm{~min}$. Afterward, the absorption maximum at $450 \mathrm{~nm}$ was measured by Thermo Multiskan EX Micro plate Photometer (Thermo Fisher Scientific, Waltham, MA, USA). SOD activity was calculated by standard curve according to the instruction of manufacturer in kit. For catalase assay, the samples were treated with $10 \mu \mathrm{l}$ of $250 \mathrm{mM} \mathrm{H}_{2} \mathrm{O}_{2}$ and incubated $5 \mathrm{~min}$ at room temperature, and the remaining $\mathrm{H}_{2} \mathrm{O}_{2}$ (not decomposed by catalase) was coupled with a substrate to generate $N$-4-antipyryl3-chloro-5-sulfonate- $p$-benzoquinonemonoimine, which has an absorption maximum at $520 \mathrm{~nm}$ and was quantified spectrophotometrically. Catalase activity was then calculated by standard curve according to the instruction of manufacturer in kit. These experiments were repeated three times independently.

\section{BIOFILM FORMATION ASSAY}

Biofilm formation assays were performed using the crystal violet (CV) assay method (Peeters et al., 2008). Bacteria were grown overnight with approximately $200 \mathrm{rpm}$ agitation and diluted at 1:50 into fresh LB media. $100 \mu \mathrm{l}$ of $10^{8} \mathrm{CFU} \mathrm{ml^{-1 }}$ mutant or wild-type bacterial suspension was added to one well of 96-well microtitre plate with sterile $\mathrm{ddH}_{2} \mathrm{O}$ serving as blanks. Cells were allowed to form biofilm at $30^{\circ} \mathrm{C}$ for $48 \mathrm{~h}$ without agitation. After the planktonic organisms were removed and each well in the plate was rinsed and air-dried, $125 \mu \mathrm{l}$ of $0.1 \%$ (w/v) CV solution was used to stain biofilm and $150 \mu \mathrm{l}$ of $33 \%$ acetic acid was added to release the bond $\mathrm{CV}$. The optical density was measured at $590 \mathrm{~nm}$ using a Thermo Multiskan EX Micro plate Photometer (Thermo Fisher Scientific, Waltham, MA, USA). This experiment was repeated three times independently with 12 replicates each.

\section{RNA EXTRACTION AND REAL-TIME PCR}

The bacterial culture (OD600=1.0) was utilized for RNA extraction after exposure to the oxidative stressor $\left(40 / 60 \mathrm{mM} \mathrm{H}_{2} \mathrm{O}_{2}\right.$ or $0.4 / 0.8 \mathrm{mM}$ paraquat, RS-1/RS-tetR) for $10 \mathrm{~min}$. Bacterial total RNA was extracted from RS-1 and RS-tetR strain respectively as described by the manual of RNeasy Protect Bacteria Mini Kit (QIAGEN) and then used for generating first strand complementary DNA (cDNA) as described in the protocol of the Takara PrimeScript RT reagent Kit with gDNA Eraser (Takara). Briefly, $1 \mathrm{ml}$ of bacterial cells were mixed with $2 \mathrm{ml}$ of RNAprotect Bacteria Reagent before incubating for $5 \mathrm{~min}$ at room temperature. A pellet was obtained after centrifugation and was then treated by TE buffer (10 mM Tris.Cl, $1 \mathrm{mM}$ EDTA; pH 8.0) containing $1 \mathrm{mg} / \mathrm{ml}$ lysozyme at room temperature for $5 \mathrm{~min}$. After detecting the RNA quantity by agarose gel electrophoresis and the quality by Nanodrop ND1000 spectrophotometer V 3.5.2 (NanoDrop Technologies, Wilmington, DE, USA), $1 \mu \mathrm{g}$ of the resulting total RNA was used at $42^{\circ} \mathrm{C}$ for 2 min to eliminate gDNA by gDNA Eraser and buffer before obtaining cDNA. Then the reverse transcription reaction was accomplished by incubating at $37^{\circ} \mathrm{C}$ for $15 \mathrm{~min}$ and then $85^{\circ} \mathrm{C}$ for $5 \mathrm{~s}$ in the presence of random RT primers. An ABI PRISM 7500 Real-Time PCR System and SYBR green fluorescence chemistry (SYBR Green I Master Kit, Roche Diagnostics) were employed to perform quantitative real-time RT-PCR amplification and analysis. Real-time PCR amplification was generated with $30 \mathrm{~s}$ of initial denaturation at $95^{\circ} \mathrm{C}$, followed by 40 cycles of $5 \mathrm{~s}$ at $95^{\circ} \mathrm{C}$, $30 \mathrm{~s}$ at $60^{\circ} \mathrm{C}$ for amplification. The reference genes (16S rRNA of both RS-1 and RS-tetR) were used to normalize the measurements between samples. Data analyses were based on change-in-cyclingthreshold method $\left(2^{-\Delta \Delta \mathrm{Ct}}\right.$; Livak and Schmittgen, 2001). RNA extraction was carried out with two replicates per strain and qPCR was performed with three replicates.

\section{EXPRESSION AND PURIFICATION OF THE TetR PROTEIN}

The tetR gene was PCR-amplified from A. avenae subsp. avenae RS-1 genome with primers that introduced a BamHI site overlapping the translation initiation codon and a SalI site downstream of the stop codon, respectively (Table S1). A 763 bp tetR-containing DNA fragment was cut with BamHI and SalI and subcloned into the pGEX6P-1 expression vector (Novagen, USA) with the same restriction enzymes, yielding pGEX6P-tetR. Subsequently, pGEX6P-tetR was transformed into E. coli BL21(DE3) and was grown in LB medium containing $100 \mu \mathrm{g} \mathrm{ml}^{-1}$ ampicillin at $30^{\circ} \mathrm{C}$ to $\mathrm{OD} 600=0.5$. Afterward, the culture was grown for an additional $3 \mathrm{~h}$ after isopropylthiogalactoside (IPTG) was added to a final concentration of $1 \mathrm{mM}$. The cells were then harvested by centrifugation at $8,000 \mathrm{~g}, 4^{\circ} \mathrm{C}$ for $10 \mathrm{~min}$, and the pellet was resuspended in $10 \mathrm{ml}$ of lysis buffer (70 mM HEPES, $20 \mathrm{mM}$ imidazole, $650 \mathrm{mM}$ $\mathrm{NaCl}, 0.5 \mathrm{mM} \beta$-mercaptoethanol, 10\% glycerol, $\mathrm{pH}$ 8; Balhana et al., 2013). Cells were disrupted on ice by ultrasonic treatment for $20 \mathrm{~min}$ with $8 \mathrm{~s}$ rest period every $16 \mathrm{~s}$ and the supernatant was recovered by removing the cellular debris through centrifugation $\left(12,000 \mathrm{~g}, 20 \mathrm{~min}, 4^{\circ} \mathrm{C}\right)$. Subsequently, TetR protein with GST-tag was separated and eluted by GST-Tag Bind resin (Sangon Biotech, China) followed by the manufacturer and the purity was confirmed by SDS-PAGE. The concentration of the purified protein was determined using the enhanced BCA Protein Assay Kit (Beyotime, China).

\section{ELECTROPHORETIC MOBILITY SHIFT ASSAYS (EMSA)}

A 292 bp fragment comprising the intergenic region between tet $R$ and pqiA' was PCR amplified from A. avenae subsp. avenae RS-1 gDNA and the $3^{\prime}$-end of the fragment was labeled by biotin to be used as probe, according to the procedures of electrophoretic mobility shift assay (EMSA) Probe Biotin Labeling Kit (Beyotime, China). A 150 bp DNA fragment from the downstream of $p q i B$ gene was worked as non-specific DNA control. Binding reactions were carried out by incubating varying concentrations of protein with $0.05 \mathrm{pmol}$ of labeled probe in a total reaction volume of $20 \mu \mathrm{l}$. The EMSA were performed using a Light-Shift chemiluminescence EMSA kit (Beyotime, China) following the manufacturer's instructions and the membrane was washed and detected following chemiluminescent method using Streptavidin-HRP conjugates and BeyoECL Plus reagents. ECL signals were captured and visualized by exposing the membrane to Hyperfilm ${ }^{\mathrm{TM}}$ (GE Healthcare). 


\section{STATISTICAL ANALYSES}

When needed, the data of quantitative assays were analyzed by SPSS 16.0 (SPSS Inc., Chicago, IL, USA) using an analysis of variance test and the mean values were compared with the least significant differences test.

Clusters of Orthologous Groups (COGs) enrichment analysis was carried out based on the Hypergeometric Test,

$$
P=\sum_{i=x}^{n} \frac{\left(\begin{array}{c}
M \\
i
\end{array}\right)\left(\begin{array}{c}
N-M \\
n-i
\end{array}\right)}{\left(\begin{array}{c}
N \\
n
\end{array}\right)}
$$

In which, $N$ means the number of genes in the RS- 1 genome, $M$ means the number of genes filling into one COG category in the RS-1 genome, $n$ means the number of differential proteins in tet $R$ mutant LC-MS/MS result and $I$ means the number of genes filling into one COG category in tetR mutant LC-MS/MS result. $P<0.01$ was used as the cutoff to define the significance.

\section{RESULTS}

\section{THE SYNTENY AND ORIGIN OF GENE CLUSTER}

Horizontal gene transfer is an important mechanism driving the evolution of microbial genomes (Gogarten and Townsend, 2005). By comparing with A. avenae subsp. avenae ATCC 19860 and A. citrulli AAC00-1, two most closely related genomes deposited in public database, we found that the upstream and downstream regions of this cluster were highly conserved (Figure 1), indicating a novel gene cluster in RS-1. This cluster encodes four genes including $p q i A A^{\prime} B$ and tet $R$ gene. The tetR gene is located upstream from the paraquat-inducible genes ( $\left.p q i A A^{\prime} B\right)$ in tandem. In the phylogenetic trees generated using the four genes in this cluster,
RS-1 always grouped together with different bacterial species, with Pseudomonas as the out-group (Figure S1). These gene trees were highly incongruent with the bacterial species tree. Based on these results, we hypothesize that this gene cluster may be horizontally transferred from a Pseudomonas ancestor.

In previous reports, TetR family members are particularly abundant in microbes and play important roles in bacterial adaptability or fitness when they are exposed to adverse environmental challenges, such as oxidative stress conditions (Ramos et al., 2005). Thus, in order to understand the role of the TetR protein in RS-1, we decided to investigate its molecular function by deleting tet $R$ gene in RS-1 strain (Figure S2).

\section{THE tetR MUTANT SHOWED DECREASED BACTERIAL GROWTH RATE AND INCREASED TOLERANCE TO OXIDATIVE STRESS}

The growth rate of the tet $R$ mutant strain RS-tet $R$ decreased significantly compared with the wild-type as well as the complemented strain RS-tetR-comp (Figure S3). Wild-type and RS-tetR-comp strains entered the log phase $1 \mathrm{~h}$ after the culture started and the OD600 reached up to 2.2 while the RS-tetR strain entered the log phase much later and its OD600 only reached 1.7.

In order to investigate the tolerance capability of $A$. avenae subsp. avenae strains to oxidative stress, we carried out a comparative analysis of the growth kinetics under different concentrations of paraquat or $\mathrm{H}_{2} \mathrm{O}_{2}$. Generally, paraquat or $\mathrm{H}_{2} \mathrm{O}_{2}$ strongly inhibited the growth of both mutant and wild-type strains. Importantly, the mutant strain showed higher resistance than wild-type strain to these reactive oxygen reagents $\left(\mathrm{H}_{2} \mathrm{O}_{2}\right.$ or paraquat) when added at mid-log phase $(\mathrm{OD} 600=0.3$; as the arrow shown in Figure $\mathrm{S} 4)$. Six different concentrations of paraquat $(0.0-1.0 \mathrm{mM})$ or $\mathrm{H}_{2} \mathrm{O}_{2}$

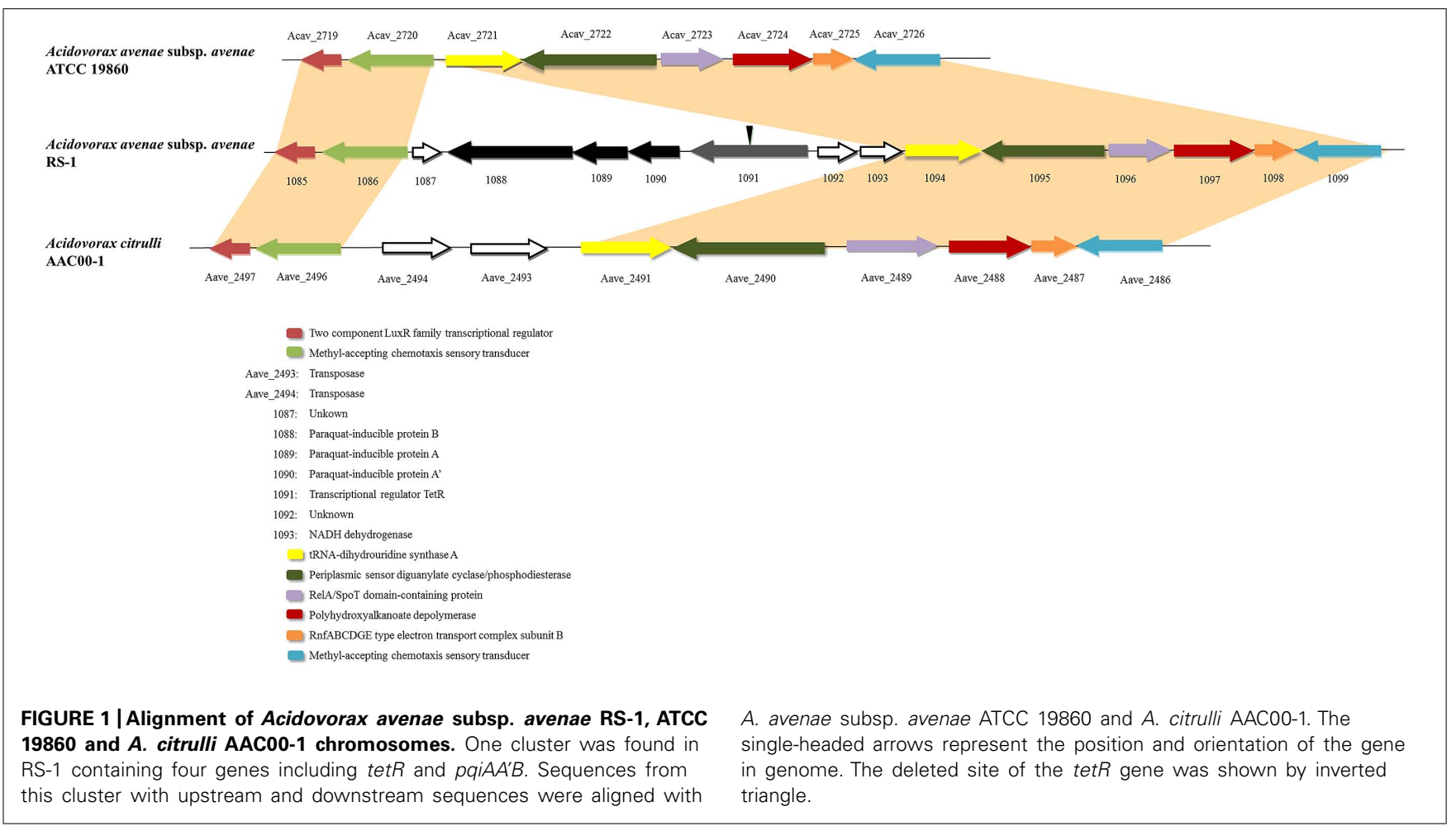




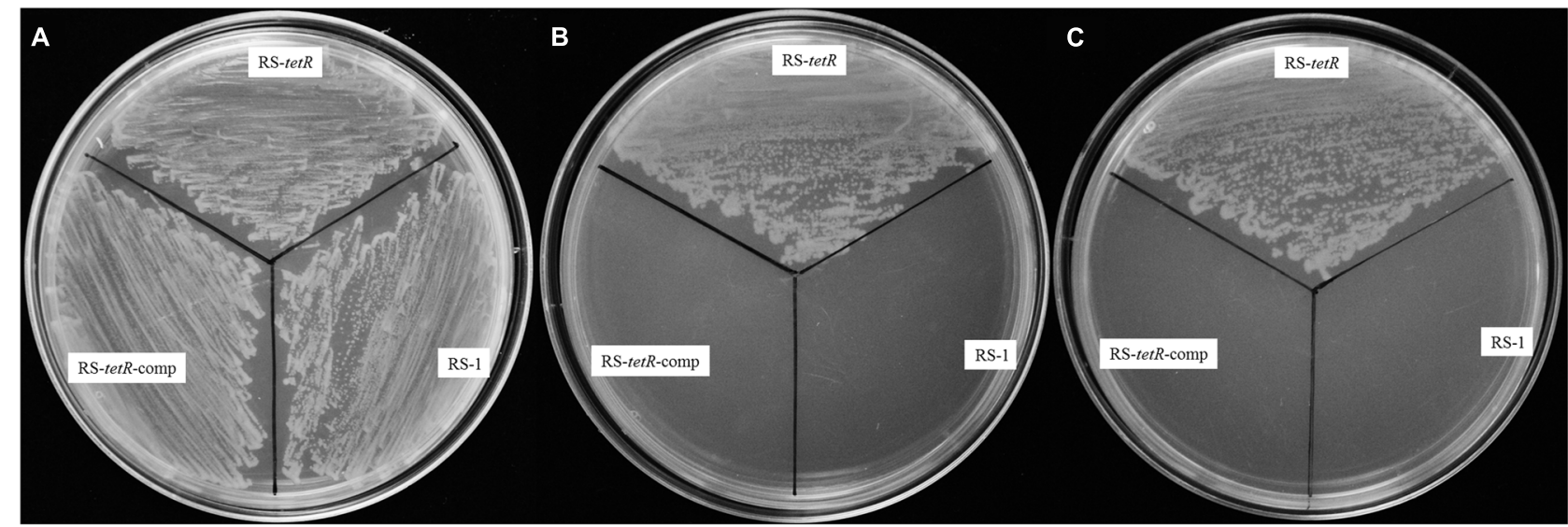

FIGURE 2 | Survival assays of RS-1, RS-tetR and RS-tetR-comp, respectively. The mutant strain grew well on the LB plates containing paraquat or $\mathrm{H}_{2} \mathrm{O}_{2}$, while the growth of wild-type and complementary cells were inhibited. (A) Growth on LB plate without oxidative reagent; (B,C) Growth on LB plate with $0.8 \mathrm{mM}$ paraquat and $60 \mathrm{mM} \mathrm{H}_{2} \mathrm{O}_{2}$, respectively.
(0-100 mM) were used to test their effects. At $0.4 \mathrm{mM}$ paraquat or $40 \mathrm{mM} \mathrm{H}_{2} \mathrm{O}_{2}$, RS-1 and RS-tetR-comp were completely inhibited, showing no further growth (Figures S4A,B,E,F), whereas the RS-tet $R$ was little affected and continued to grow. At $0.8 \mathrm{mM}$ of paraquat or $60 \mathrm{mM}$ of $\mathrm{H}_{2} \mathrm{O}_{2}$, growth of RS-tetR strain was inhibited (Figures S4C,D), whereas RS-1 and RS-tetR-comp cells started to die. Moreover, the results from LB plate assay were consistent with those of growth curves. The RS-tetR grew well on LB plates containing $0.8 \mathrm{mM}$ paraquat or $60 \mathrm{mM} \mathrm{H}_{2} \mathrm{O}_{2}$, while RS-1 and RS-tetR-comp was inhibited (Figure 2). These data suggest that TetR is involved in negative regulation of cell growth and adaption under oxidative stress.

\section{DIFFERENCE IN BIOFILM FORMATION, BUT NO DIFFERENCE IN BACTERIAL VIRULENCE}

The morphological appearance and thickness of biofilm showed obvious differences after $48 \mathrm{~h}$ of adhesion at $30^{\circ} \mathrm{C}$ without agitation. Particularly, RS-tetR strain formed a thicker biofilm compared with RS-1 and RS-tetR-comp strains. When quantified, RS-tet $R$ yielded readings twice as high as RS-1 and RS-tetR-comp (Figure 3). The quantitative data confirmed that the mutant strain exhibited significantly $(P<0.05)$ higher biofilm-forming capability compared to the other two strains. However, the virulence did not show significant difference comparing among wild-type, mutant and complementation strains by observation of symptoms and analysis of lesion lengths 14 days post-inoculation (Figure S5).

\section{INCREASED ACTIVITIES OF SOD AND CATALASE IN tetR MUTANT CELLS WITH OXIDATIVE STRESS}

Superoxide dismutase and catalase in cytoplasm of bacterial cells play a pivotal role in protection against superoxide and peroxide stress (Henriques et al., 1998; Inaoka et al., 1999). They are highly efficient enzymes and likely to be transiently induced (Hassett and Cohen, 1989). Our results in Figure 4 showed that their enzyme activities were increased in response to oxidative stress compared to the untreated control (Figure 4). More importantly, the RStet $R$ mutant strain showed markedly higher levels of catalase and SOD activities compared to wild-type and complemented strains (Figure 4). The quantitative analysis of SOD activity showed that the absence of TetR led to $\sim 2.3$-fold increase in enzyme activity in paraquat treatment and $\sim 2$.2-fold in the $\mathrm{H}_{2} \mathrm{O}_{2}$ treatment. The quantitative catalase activity analysis yielded similar results: deletion of tet $R$ resulted in $\sim 2.7$-fold and $\sim 2$.1-fold increase in $\mathrm{H}_{2} \mathrm{O}_{2}$-treated and paraquat-treated samples, respectively. These results raised the question as to whether TetR can also influence expression of genes encoding other oxidative stress detoxifying enzymes, such as $\operatorname{sod} A B, k a t A, a h p C F$ and hemAXCDBL (Zuber, 2009). We therefore carried out LC-MS and quantitative PCR analysis to address this issue.

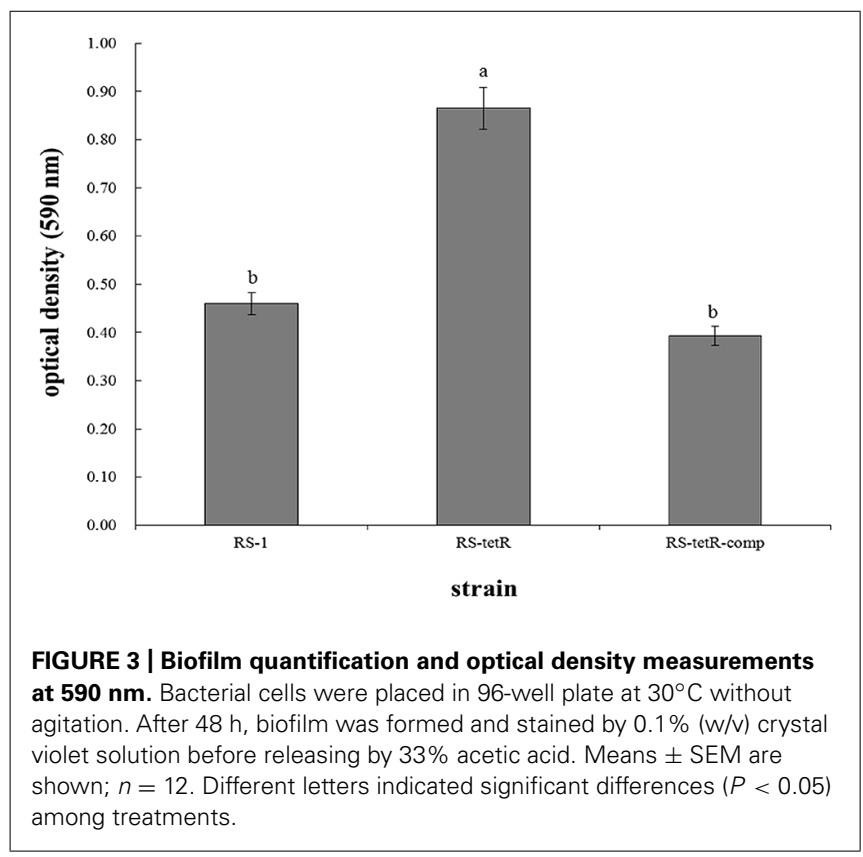




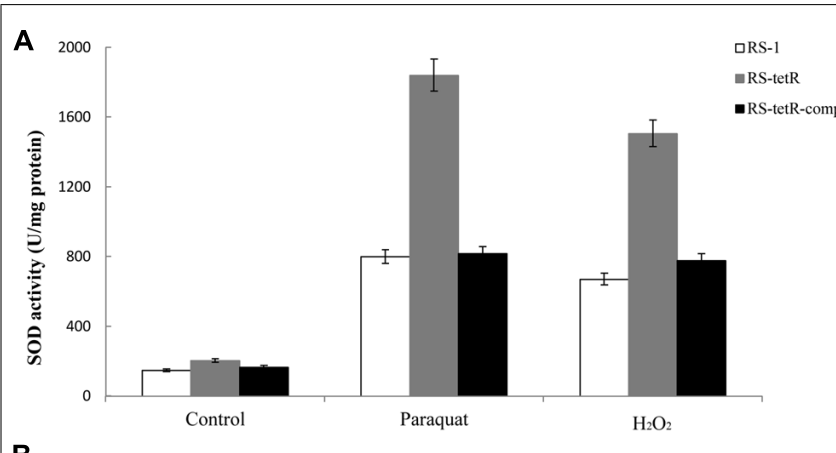

B

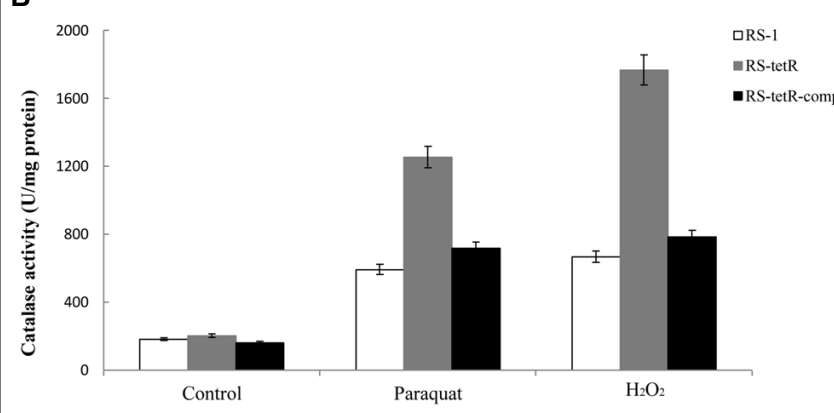

FIGURE 4 | Total SOD (A) and catalase (B) activities in response to superoxide and peroxide stress. Enzyme activities of different strains were evaluated using cytoplasmic proteins after $60 \mathrm{~min}$ induction with oxidative compounds $\left(0.4 / 0.8 \mathrm{mM}\right.$ paraquat or $40 / 60 \mathrm{mM} \mathrm{H}_{2} \mathrm{O}_{2}$, RS-1 and RS-tetR-comp/RS-tetR). Error bars indicated standard deviations from three independent experiments.

\section{IDENTIFICATION OF PROTEINS REGULATED BY TetR}

In order to investigate how many proteins can be influenced by TetR under oxidative conditions, we employed 1D SDS-PAGE to compare cytoplasmic proteins of RS-1 and RS-tetR, prepared as described in Section "Materials and Methods" (Figure 5). The resultant protein bands were further digested and peptides were then analyzed by LC-MS/MS subsequently.

The protein profiling data of LC-MS/MS from two biological replicates revealed a non-redundant list of proteins, after removing overlapping entries, with high (>98\%) confidence. The results clearly suggest differential expression of these newly identified cytoplasmic proteins between wild-type and tet $R$ mutant strains. In total, there are 111 proteins identified (Tables S2 and S3). Specifically, 15 proteins were only identified in RS-1 while 96 proteins were identified only in RS-tetR. These proteins are mainly associated with oxidative stress response, detoxification, and biofilm-formation. COG enrichment suggested that there were more proteins involved in energy production and conversion, cell motility, post-translational modification in the RS-tet $R$ strain, compared to RS-1 $(P<0.01$, hypergeometric distribution test); whereas the wild-type strain produced more proteins involved in coenzyme transport and metabolism, amino acid transport and metabolism, and cell division (Figure S6). Overall, these results provide an explanation for the observed physiological changes caused by TetR and support our main hypothesis that this gene cluster plays a key role in bacterial survival under oxidative stress.

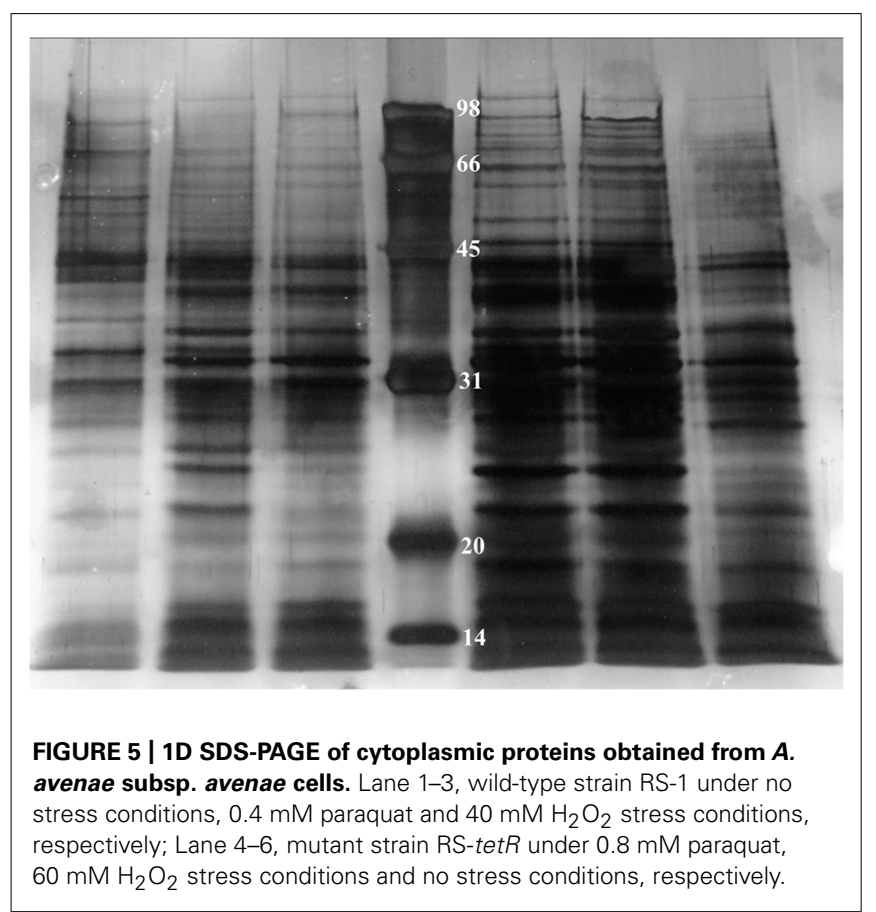

\section{QUANTITATIVE PCR ANALYSIS OF THE tetR-REGULATED GENES}

The LC-MS/MS study exhibited a comprehensive profile of proteins whose coding genes are regulated by the TetR regulator under oxidative stress. For further confirmation, we selected 11 genes from the proteomic profile which were involved in oxidative stress response or biofilm-formation, or encoded detoxifying enzymes. We examined their gene expression with quantitative real-time PCR. The results in Figure $\mathbf{6}$ showed different fold change in gene expression regulated by tet $R$ comparing mutant to wild-type strain. As expected, the expression of $p q i A^{\prime} A B$ was significantly up-regulated in the RS-tetR strain (6.2-, 6.5-, 7.8-fold, respectively). Similar results were obtained for genes $\operatorname{sod} A, a h p F$ and $k a t A$, which encode SOD, alkyl hydroperoxide reductase, and catalase, respectively (Figure 6). Up-regulated expression in these genes is expected to lead to increase in detoxifying enzyme activities, as shown in SOD and catalase activities assay (Figure 6). Moreover, the increased detoxifying enzyme activity can also contribute to the higher resistance to paraquat and $\mathrm{H}_{2} \mathrm{O}_{2}$. Flagella are important for bacterial colonization and biofilm formation (Conrad, 2012; Bogino etal., 2013; Ren etal., 2013). Quantitative real-time PCR showed that the gene expression level of fliL and flaB, two flagella-associated genes, was 1.4-fold and 1.8 -fold higher in the absence of TetR. The $c l p A B$ gene family plays a role in synthesis of stable and native proteins, which are required for intracellular replication, stress tolerance, and biofilm formation of bacteria, in the presence of ATP (Wawrzynow etal., 2003; Frees etal., 2004). Thereby it was not surprising to see these genes up-regulated in the absence of the tet $R$ regulator.

\section{TetR BINDS TO pqiA'-tetR INTERGENIC REGION}

To investigate whether the repression of the genes on the gene cluster by TetR occurs via physical interaction between TetR and 


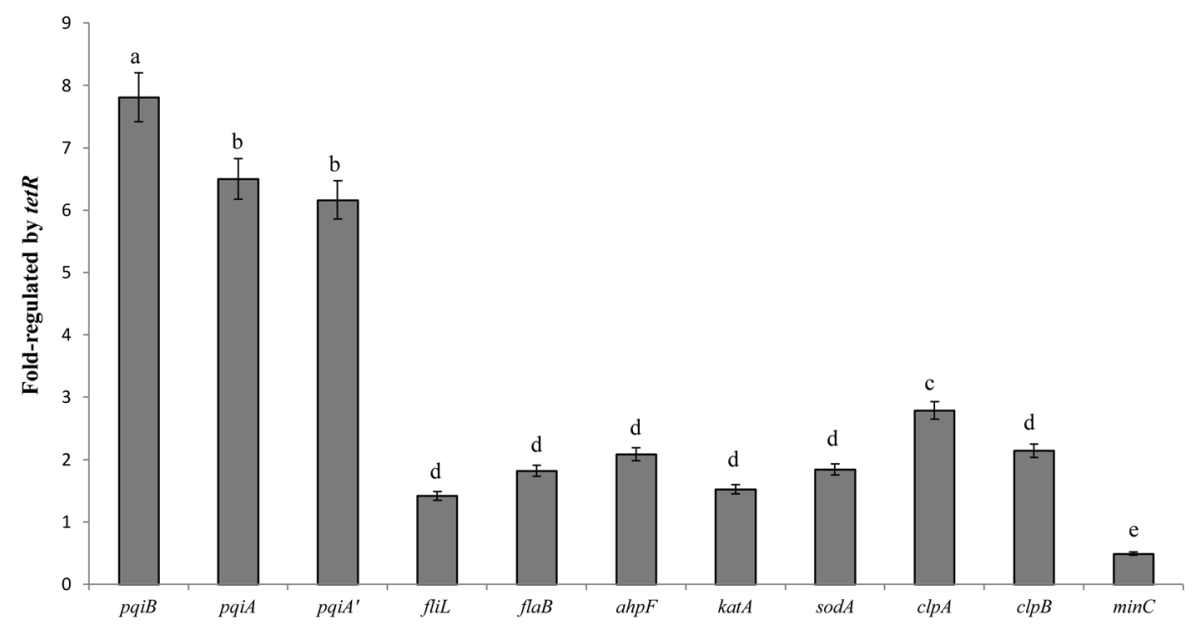

FIGURE 6 | Quantitative PCR analysis shown as fold change in gene expression regulated by tet $\boldsymbol{R}$. The data were quantified by the change-in-cycling-threshold method $\left(2^{-\Delta \Delta C t}\right)$ using the 16S rRNA for normalization. Total RNA was extracted from RS-1 and RS-tet $R$ cells exposed to the oxidative compounds for $10 \mathrm{~min}$. Error bars indicated standard deviations from three independent experiments. Different letters indicated significant differences $(P<0.05)$ among treatments. the promoter of the gene cluster, we performed EMSA using a 292 bp putative promoter fragment of the $p q i A^{\prime}-t e t R$ intergenic region from $A$. avenae subsp. avenae RS-1 (Figure 7A). We purified the TetR protein with GST tag (about $48 \mathrm{kDa}$ ) and confirmed it by SDS-PAGE with silver staining (Figures S7A,B). After mixing the biotin-labeled probe with TetR, a band with substantial mobility shift corresponding to a TetR-DNA complex was detected (Figure 7B, Lane 3-5). When TetR concentration was increased, an increase in the shifted band was observed (Figure $7 \mathbf{B}$, Lane 3-5). This result indicates that the binding of TetR to the DNA fragment is concentration dependent. As a control, we showed that there was no mobility shift of the probe when TetR was not added (Figure 7B, Lane 2). In addition, a strong binding shift appeared when unlabeled non-specific DNA was added (Figure 7B, Lane 1); while when unlabeled cold probe was added, it abolished the binding, demonstrating the binding sensitivity and specificity of TetR for this intergenic region (Figure 7B, Lane 6-7).

\section{DISCUSSION}

It is believed that pathogenic bacteria can acquire and integrate foreign DNA into its chromosome. This process has been hypothesized to give advantages to the pathogenic bacteria (Dobrindt et al., 2004). A. avenae subsp. avenae, the phytopathogen causing BBS disease, has developed several mechanisms to defend itself against oxidative stress, including induction of protective enzymes against peroxide/superoxide and adjustment of efflux pumps. HGT is an efficient means to acquire foreign DNA, which helps to adjust cellular responses to successfully survive environmental challenges, such as oxidative stress.

Many methods have been developed to detect HGT including GC content, codon usage and phylogenetic tree analyses (Eisen, 2000). In these, phylogenetic tree has proven to be the "golden standard" for HGT detection (Bansal et al., 2012). Our phylogenetic tree analysis suggested that this gene cluster might be acquired

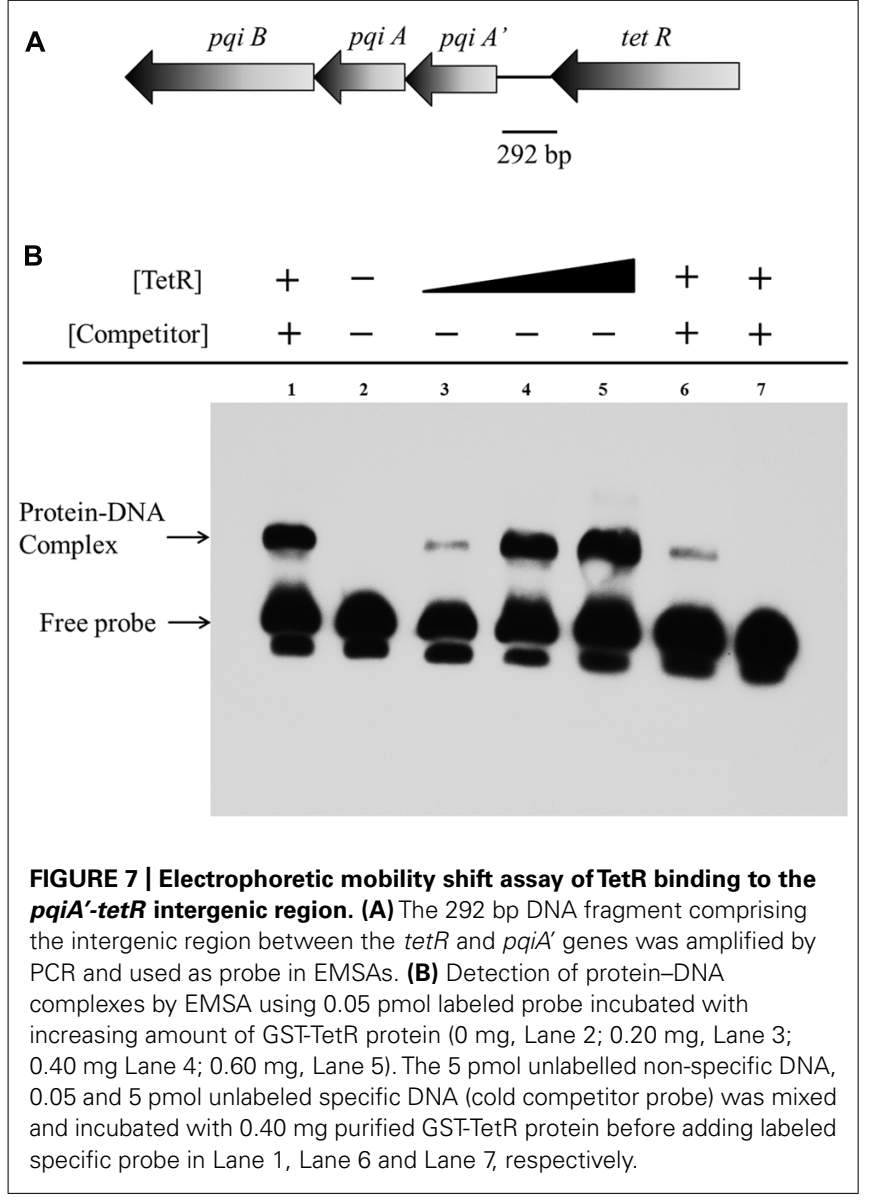

from a Pseudomonas ancestor as many Pseudomonas species clustered with RS-1 (Figure S1). Consistent with this evidence, $A$. avenae RS-1 and most Pseudomonas strains are both soil dwellers; 
many Pseudomonas strains are plant pathogenic bacteria (Sarkar and Guttman, 2004). Thus, RS-1 may have gained these genes from a Pseudomonas donor.

In most cases, TetR-like transcriptional factors are believed to have two domains responsible for signal perception and DNAbinding, respectively (Hillerich and Westpheling, 2008). Besides, it was reported that the TetR protein regulates many genes and pathways in bacteria that are involved in secondary metabolism, MDR, and so on (Ramos et al., 2005; Hillerich and Westpheling, 2008). The deletion of the tetR gene in RS-1 rendered the bacterium more resistant to oxidative conditions, suggesting that it normally functions to regulate the onset of anti-oxidative stress response. Moreover, the LC-MS/MS results revealed that the TetR can regulate expression of multi-proteins in RS-1.

Biofilm-forming capacity of bacteria is important for their survival and infection on host cells. Therefore, studies on the regulatory mechanisms governing biofilm formation are important and could eventually lead to prevention of or therapy for pathogen infections. Nevertheless, the regulation of biofilm formation is too complex and multifactorial because of the varying environmental factors, including osmolarity, temperature, anaerobiosis, and levels of iron, ethanol, glucose, nitrites, and citrate (Prigent-Combaret et al., 1999; Schlag et al., 2007). In addition, there are a number of endogenous proteins, for instance CsrA, Crc, BfdR, and LuxR, which regulate biofilm-forming ability of bacteria (O’Toole et al., 2000; Jackson et al., 2002; Huang et al., 2013; HuiQiu et al., 2013). Here we reported that the tetR gene in a gene cluster of $A$. avenae subsp. avenae also affected its biofilm-forming ability. To access expression level of biofilmforming associated genes, we employed LC-MS/MS analysis and real-time PCR study, and found activation of an array of flagellar genes and $c l p A B$ genes in the absence of TetR (Tables S2 and S3, Figure 6). On the other hand, the proteins down-regulated (such as methylcrotonoyl-CoA carboxylase and MinC) in the tetR mutant, mainly belong to bacterial catabolic pathways and regulator of cell division and growth (Tables S2 and S3; Höschle et al., 2005; Aguilar et al., 2008; Bramkamp and van Baarle, 2009; Lutkenhaus, 2009). In particular, the decreased $\min C$ gene expression can cause slower cell growth, which may help bacteria to withstand arduous conditions. These results also provide evidence supporting the role of TetR as a positive regulator of genes promoting cell growth.

As a transcriptional regulator, the TetR protein binds to the promoter of the gene cluster directly, as EMSA showed (Figure 7). Mutation of the tet $R$ gene resulted in activation of the pqiAA'B genes, suggesting that TetR negatively controls the transcript levels of $p q i A A^{\prime} B$. This result is consistent with our observations that the mutant displayed increased levels of resistance to paraquat and $\mathrm{H}_{2} \mathrm{O}_{2}$.

With the exception of TetR regulator, there are some other known regulators associated with oxidative stress regulation, such as OxyR or PerR. Although similar properties make them functionally analogous with each other, genetic evidence revealed that they have much difference on protein structures and functional mechanisms. OxyR, a member of the LysR family, is a well-characterized positive regulator of the adaptive response to $\mathrm{H}_{2} \mathrm{O}_{2}$ stress in $E$. coli and in Salmonella enterica serovar typhimurium (Zheng et al.,
1998; Helmann, 2002), and a negative regulator of catalase expression in Neisseria gonorrhoeae (Tseng et al., 2003). Recently, more researches have shifted to favor a model for OxyR activation. It was believed a specific disulfide bond formation was required in the oxidative activation of OxyR, rather than being chemically modified by individual cysteine (Cys) residues (Helmann, 2002; Lee et al., 2004). PerR is a metal-dependent peroxide sensors that regulate inducible peroxide-defense genes, such as catalase gene katA, alkyl hydroperoxide reductase gene $\operatorname{h} p C F$ (Horsburgh et al., 2001; Lee and Helmann, 2006). PerR is as well required for virulence and iron storage proteins in Staphylococcus aureus (Horsburgh et al., 2001). These features separate PerR functionally and mechanistically from TetR and OxyR regulators. Here, we did not find the TetR controlling virulence in A. avenae subsp. avenae by observing symptoms and analyzing lesion lengths 14 days post-inoculation (Figure S5). Most of the fully identified and characterized TetRfamily repressors were associated with biosynthesis of antibiotics, efflux pumps, and osmotic stress (Aramaki et al., 1993, 1995). As a regulator of adaptive response to $\mathrm{H}_{2} \mathrm{O}_{2}$ stress, it was not known whether paraquat or $\mathrm{H}_{2} \mathrm{O}_{2}$ was the direct modulator for TetR protein activity. Future studies are required to cope with this question.

It is well-known that there is a balance between different factors contributing to fitness in bacteria. The trade-off hypothesis in pathogen evolution states that higher benefit in one aspect is correlated to lower benefit in another aspect (Alizon et al., 2009). Based on the trade-off hypothesis, there must be undesirable side effects derived from over-expression of the TetR-regulated genes. Our results showed that over-expression of the TetR-regulated genes in the tetR mutant led to low cell growth rate under nonoxidative stress conditions. In favorable growth conditions, fast growth would be more important to bacteria than keeping its defense heightened. TetR is a repressor in the operon to regulate the pqiAA'B genes to achieve the balance between fast growth and resistance to arduous surroundings. This feedback mechanism is of high flexibility, which is important to bacterial adaptability. TetR-like repressors, such as PrqR, Aur1R, EthR and CifR, with similar mechanisms are also found in other bacteria (Babykin et al., 2003; Engohang-Ndong et al., 2004; MacEachran et al., 2008; Novakova et al., 2010). In Vibrio cholerae, HapR (another TetR regulator) is found to play a positive role on detachment of $V$. cholerae to the gastrointestinal epithelium as well as a negative effect on biofilm formation (Silva et al., 2003). We still don't know exactly the positive role of the tetR gene. However, based on the differential protein profiles between tet $R$ mutant and wild-type strain, we hypothesize that TetR also plays positive roles, including promoting cell growth. More research is needed to reveal other physiological roles of TetR.

\section{ACKNOWLEDGMENTS}

We would like to thank Dr. Mawsheng Chern and Dr. Tong Wei of University of California, Davis for reviewing the manuscript and giving helpful comments. This study was supported by the Special Fund for Agro-scientific Research of China in the Public Interest (201303015), National Natural Science Foundation of China (31200003), the Scholarship Award for Excellent Doctoral Student granted by Ministry of Education, 12th Five 
Years Key Programs for Science and Technology Development of China (2012BAK11B02; 2012BAK11B06), Zhejiang Provincial Nature Science Foundation of China (LY12C14007), and China Post-doctoral Special Foundation (317000-X91206).

\section{SUPPLEMENTARY MATERIAL}

The Supplementary Material for this article can be found online at: http://www.frontiersin.org/journal/10.3389/fmicb.2014.00547/ abstract

\section{REFERENCES}

Aguilar, J., Diaz-Perez, C., Diaz-Perez, A., Rodriguez-Zavala, J., Nikolau, B., and Campos-Garcia, J. (2008). Substrate specificity of the 3-methylcrotonyl coenzyme A (CoA) and geranyl-CoA carboxylases from Pseudomonas aeruginosa. J. Bacteriol. 190, 4888-4893. doi: 10.1128/JB.00454-08

Alizon, S., Hurford, A., Mideo, N., and Van Baalen, M. (2009). Virulence evolution and the trade-off hypothesis: history, current state of affairs and the future. $J$. Evol. Biol. 22, 245-259. doi: 10.1111/j.1420-9101.2008.01658.

Altschul, S. F., Madden, T. L., Schaffer, A. A., Zhang, J. H., Zhang, Z., Miller, W., et al. (1997). Gapped BLAST and PSI-BLAST: a new generation of protein database search programs. Nucleic Acids Res. 25, 3389-3402. doi: 10.1093/nar/25.17.3389

Aramaki, H., Sagara, Y., Hosoi, M., and Horiuchi, T. (1993). Evidence for autoregulation of camR, which encodes a repressor for the cytochrome P-450cam hydroxylase operon on the Pseudomonas putida CAM plasmid. J. Bacteriol. 175, 7828-7833.

Aramaki, H., Yagi, N., and Suzuki, M. (1995). Residues important for the function of a multihelical DNA binding domain in the new transcription factor family of Cam and Tet repressors. Protein Eng. 8, 1259-1266. doi: 10.1093/protein/8.12.1259

August, P. R., Tang, L., Yoon, Y. J., Ning, S., Müller, R., Yu, T.-W., et al. (1998). Biosynthesis of the ansamycin antibiotic rifamycin: deductions from the molecular analysis of the rif biosynthetic gene cluster of Amycolatopsis mediterranei $\$ 699$. Chem. Biol. 5, 69-79. doi: 10.1016/S1074-5521(98)90141-7

Babykin, M., Sidoruk, K., Zinchenko, V., Nefedova, L., Cerff, R., and Shestakov, S. (2003). On the involvement of the regulatory gene prqR in the development of resistance to methyl viologen in cyanobacterium Synechocystis sp. PCC 6803. Russ. J. Genet. 39, 18-24. doi: 10.1023/A:1022010525032

Balhana, R. J., Swanston, S. N., Coade, S., Withers, M., Sikder, M. H., Stoker, N. G., et al. (2013). bkaR is a TetR-type repressor that controls an operon associated with branched chain keto-acid metabolism in Mycobacteria. FEMS Microbiol. Lett. 345, 132-140. doi: 10.1111/1574-6968.12196

Bansal, M. S., Alm, E. J., and Kellis, M. (2012). Efficient algorithms for the reconciliation problem with gene duplication, horizontal transfer and loss. Bioinformatics 28, i283-i291. doi: 10.1093/bioinformatics/bts225

Bogino, P. C., Oliva Mde, L., Sorroche, F. G., and Giordano, W. (2013). The role of bacterial biofilms and surface components in plant-bacterial associations. Int. J. Mol. Sci. 14, 15838-15859. doi: 10.3390/ijms140815838

Bramkamp, M., and van Baarle, S. (2009). Division site selection in rod-shaped bacteria. Curr. Opin. Microbiol. 12, 683-688. doi: 10.1016/j.mib.2009.10.002

Castresana, J. (2000). Selection of conserved blocks from multiple alignments for their use in phylogenetic analysis. Mol. Biol. Evol. 17, 540-552. doi: 10.1093/oxfordjournals.molbev.a026334

Cho, Y.-H., Kim, E.-J., Chung, H.-J., Choi, J.-H., Chater, K. F., Ahn, B.-E., et al. (2003). The pqrAB operon is responsible for paraquat resistance in Streptomyces coelicolor. J. Bacteriol. 185, 6756-6763. doi: 10.1128/JB.185.23.6756-6763.2003

Ciccarelli, F. D., Doerks, T., Von Mering, C., Creevey, C. J., Snel, B., and Bork, P. (2006). Toward automatic reconstruction of a highly resolved tree of life. Science 311, 1283-1287. doi: 10.1126/science.1123061

Conrad, J. C. (2012). Physics of bacterial near-surface motility using flagella and type IV pili: implications for biofilm formation. Res. Microbiol. 163, 619-629. doi: 10.1016/j.resmic.2012.10.016

Dobrindt, U., Hochhut, B., Hentschel, U., and Hacker, J. (2004). Genomic islands in pathogenic and environmental microorganisms. Nat. Rev. Microbiol. 2, 414-424. doi: $10.1038 /$ nrmicro884

Eisen, J. A. (2000). Horizontal gene transfer among microbial genomes: new insights from complete genome analysis. Curr. Opin. Genet. Dev. 10, 606-611. doi: 10.1016/S0959-437X(00)00143-X
Engohang-Ndong, J., Baillat, D., Aumercier, M., Bellefontaine, F., Besra, G. S., Locht, C., et al. (2004). EthR, a repressor of the TetR/CamR family implicated in ethionamide resistance in mycobacteria, octamerizes cooperatively on its operator. Mol. Microbiol. 51, 175-188. doi: 10.1046/j.1365-2958.2003.03809.x

Fang, F. C., Degroote, M. A., Foster, J. W., Bäumler, A. J., Ochsner, U., Testerman, T., et al. (1999). Virulent Salmonella typhimurium has two periplasmic $\mathrm{Cu}, \mathrm{Zn}$-superoxide dismutases. Proc. Natl. Acad. Sci. U.S.A. 96, 7502-7507. doi: 10.1073/pnas.96.13.7502

Frees, D., Chastanet, A., Qazi, S., Sørensen, K., Hill, P., Msadek, T., et al. (2004). Clp ATPases are required for stress tolerance, intracellular replication and biofilm formation in Staphylococcus aureus. Mol. Microbiol. 54, 1445-1462. doi: $10.1111 /$ j.1365-2958.2004.04368.x

Gao, G., Lu, H., Huang, L., and Hua, Y. (2005). Construction of DNA damage response gene pprI function-deficient and function-complementary mutants in Deinococcus radiodurans. Chin. Sci. Bull. 50, 311-316.

Gogarten, J. P., and Townsend, J. P. (2005). Horizontal gene transfer, genome innovation and evolution. Nat. Rev. Microbiol. 3, 679-687. doi: 10.1038/nrmicro1204

Guindon, S., and Gascuel, O. (2003). A simple, fast, and accurate algorithm to estimate large phylogenies by maximum likelihood. Syst. Biol. 52, 696-704. doi: $10.1080 / 10635150390235520$

Hassett, D. J., and Cohen, M. S. (1989). Bacterial adaptation to oxidative stress: implications for pathogenesis and interaction with phagocytic cells. FASEB J. 3, 2574-2582.

Helmann, J. D. (2002). OxyR: a molecular code for redox sensing? Sci. STKE 2002, pe46.

Henriques, A. O., Melsen, L. R., and Moran, C. P. Jr. (1998). Involvement of superoxide dismutase in spore coat assembly in Bacillus subtilis. J. Bacteriol. 180, 2285-2291.

Hillerich, B., and Westpheling, J. (2008). A new TetR family transcriptional regulator required for morphogenesis in Streptomyces coelicolor. J. Bacteriol. 190, 61-67. doi: 10.1128/JB.01316-07

Horsburgh, M. J., Clements, M. O., Crossley, H., Ingham, E., and Foster, S. J. (2001). PerR controls oxidative stress resistance and iron storage proteins and is required for virulence in Staphylococcus aureus. Infect. Immun. 69, 3744-3754. doi: 10.1128/IAI.69.6.3744-3754.2001

Höschle, B., Gnau, V., and Jendrossek, D. (2005). Methylcrotonyl-CoA and geranyl-CoA carboxylases are involved in leucine/isovalerate utilization ( $\mathrm{Liu}$ ) and acyclic terpene utilization (Atu), and are encoded by $l i u B / l i u D$ and $a t u C / a t u F$, in Pseudomonas aeruginosa. Microbiology 151, 3649-3656. doi: 10.1099/mic.0. 28260-0

Huang, T.-P., Lu, K.-M., and Chen, Y.-H. (2013). A novel two-component response regulator links $r p f$ with biofilm formation and virulence of Xanthomonas axonopodis pv. citri. PLoS ONE 8:e62824. doi: 10.1371/journal.pone.0062824

HuiQiu, W., Enli, X., Yangyang, Y., Yanli, T., Guoliang, Q., Fengquan, L., et al. (2013). Gene cloning and characterization of luxR transcriptional regulator from Erwinia amylovora. J. Agric. Biotechnol. 21, 725-733.

Imlay, J. A. (2013). The molecular mechanisms and physiological consequences of oxidative stress: lessons from a model bacterium. Nat. Rev. Microbiol. 11, 443-454. doi: $10.1038 /$ nrmicro3032

Inaoka, T., Matsumura, Y., and Tsuchido, T. (1999). SodA and manganese are essential for resistance to oxidative stress in growing and sporulating cells of Bacillus subtilis. J. Bacteriol. 181, 1939-1943.

Jackson, D. W., Suzuki, K., Oakford, L., Simecka, J. W., Hart, M. E., and Romeo, T. (2002). Biofilm formation and dispersal under the influence of the global regulator CsrA of Escherichia coli. J. Bacteriol. 184, 290-301. doi: 10.1128/JB.184.1.290-301.2002

Lee, C., Lee, S. M., Mukhopadhyay, P., Kim, S. J., Lee, S. C., Ahn, W.-S., et al. (2004). Redox regulation of OxyR requires specific disulfide bond formation involving a rapid kinetic reaction path. Nat. Struct. Mol. Biol. 11, 1179-1185. doi: $10.1038 / \mathrm{nsmb} 856$

Lee, J.-W., and Helmann, J. D. (2006). The PerR transcription factor senses $\mathrm{H}_{2} \mathrm{O}_{2}$ by metal-catalysed histidine oxidation. Nature 440, 363-367. doi: 10.1038/nature04537

Li, Y. R., Zou, H. S., Che, Y. Z., Cui, Y. P., Guo, W., Zou, L. F., et al. (2011). A novel regulatory role of HrpD6 in regulating $h r p$-hrc-hpa genes in Xanthomonas oryzae pv. oryzicola. Mol. Plant Microbe Interact. 24, 1086-1101. doi: 10.1094/MPMI09-10-0205

Lin, S., Lin, Z., Yao, G., Deng, C., Yang, P., and Zhang, X. (2007). Development of microwave-assisted protein digestion based on trypsin-immobilized magnetic 
microspheres for highly efficient proteolysis followed by matrix-assisted laser desorption/ionization time-of-flight mass spectrometry analysis. Rapid Commun. Mass Spectrom. 21, 3910-3918. doi: 10.1002/rcm.3283

Liu, H., Tian, W.-X., Ibrahim, M., Li, B., Zhang, G.-Q., Zhu, B., et al. (2012). Characterization of pilP, a gene required for twitching motility, pathogenicity, and biofilm formation of Acidovorax avenae subsp. avenae RS-1. Eur. J. Plant Pathol. 134, 551-560. doi: 10.1007/s10658-012-0038-x

Livak, K. J., and Schmittgen, T. D. (2001). Analysis of relative gene expression data using real-time quantitative PCR and the $2^{-\Delta \Delta C t}$ method. Methods 25, 402-408. doi: $10.1006 /$ meth.2001.1262

Lutkenhaus, J. (2009). Min oscillation in bacteria. Cell. Oscillatory Mech. 641, 49-61.

MacEachran, D. P., Stanton, B. A., and O'toole, G. A. (2008). Cif is negatively regulated by the TetR family repressor CifR. Infect. Immun. 76, 3197-3206. doi: 10.1128/IAI.00305-08

Nogueira, T., Rankin, D. J., Touchon, M., Taddei, F., Brown, S. P., and Rocha, E. P. C. (2009). Horizontal gene transfer of the secretome drives the evolution of bacterial cooperation and virulence. Curr. Biol. 19, 1683-1691. doi 10.1016/j.cub.2009.08.056

Novakova, R., Kutas, P., Feckova, L., and Kormanec, J. (2010). The role of the TetRfamily transcriptional regulator Aur $1 \mathrm{R}$ in negative regulation of the auricin gene cluster in Streptomyces aureofaciens CCM 3239. Microbiology 156, 2374-2383. doi: 10.1099/mic.0.037895-0

Ochman, H., Lawrence, J. G., and Groisman, E. A. (2000). Lateral gene transfer and the nature of bacterial innovation. Nature 405, 299-304. doi: 10.1038/ 35012500

O’Toole, G. A., Gibbs, K. A., Hager, P. W., Phibbs, P. V., and Kolter, R. (2000). The global carbon metabolism regulator $\mathrm{Crc}$ is a component of a signal transduction pathway required for biofilm development by Pseudomonas aeruginosa. J. Bacteriol. 182, 425-431. doi: 10.1128/JB.182.2.425-431.2000

Peeters, E., Nelis, H. J., and Coenye, T. (2008). Comparison of multiple methods for quantification of microbial biofilms grown in microtiter plates. J. Microbiol. Methods 72, 157-165. doi: 10.1016/j.mimet.2007.11.010

Prigent-Combaret, C., Vidal, O., Dorel, C., and Lejeune, P. (1999). Abiotic surface sensing and biofilm-dependent regulation of gene expression in Escherichia coli. J. Bacteriol. 181, 5993-6002.

Ramos, J. L., Martínez-Bueno, M., Molina-Henares, A. J., Terán, W., Watanabe, K., Zhang, X., et al. (2005). The TetR family of transcriptional repressors. Microbiol. Mol. Biol. Rev. 69, 326-356. doi: 10.1128/MMBR.69.2.326-356.2005

Rand, J. D., Danby, S. G., Greenway, D. L., and England, R. R. (2006). Increased expression of the multidrug efflux genes acrAB occurs during slow growth of Escherichia coli. FEMS Microbiol. Lett. 207, 91-95. doi: 10.1111/j.15746968.2002.tb11034.x

Ren, Z., Jiang, W., Ni, X., Lin, M., Zhang, W., Tian, G., et al. (2013). Multiplication of Acidovorax citrulli in planta during infection of melon seedlings requires the ability to synthesize leucine. Plant Pathol. 63, 784-791. doi: 10.1111/ppa.12156

Sarkar, S. F., and Guttman, D. S. (2004). Evolution of the core genome of Pseudomonas syringae, a highly clonal, endemic plant pathogen. Appl. Environ. Microbiol. 70, 1999-2012. doi: 10.1128/AEM.70.4.1999-2012.2004

Schägger, H., and Von Jagow, G. (1987). Tricine-sodium dodecyl sulfatepolyacrylamide gel electrophoresis for the separation of proteins in the range from 1 to $100 \mathrm{kDa}$. Anal. Biochem. 166, 368-379. doi: 10.1016/0003-2697(87)90587-2

Schlag, S., Nerz, C., Birkenstock, T. A., Altenberend, F., and Götz, F. (2007). Inhibition of staphylococcal biofilm formation by nitrite. J. Bacteriol. 189, 7911-7919. doi: 10.1128/JB.00598-07

Sies, H. (1997). Oxidative stress: oxidants and antioxidants. Exp. Physiol. 82, 291-295.

Silva, A. J., Pham, K., and Benitez, J. A. (2003). Haemagglutinin/protease expression and mucin gel penetration in El Tor biotype Vibrio cholerae. Microbiology 149, 1883-1891. doi: 10.1099/mic.0.26086-0

Simon, R., Priefer, U., and Pühler, A. (1983). A broad host range mobilization system for in vivo genetic engineering: transposon mutagenesis in gram negative bacteria. Nat. Biotechnol. 1, 784-791. doi: 10.1038/nbt1183-784

Slade, D., and Radman, M. (2011). Oxidative stress resistance in Deinococcus radiodurans. Microbiol. Mol. Biol. Rev. 75, 133-191. doi: 10.1128/MMBR.00015-10
Smith, M. D., and Guild, W. R. (1980). Improved method for conjugative transfer by filter mating of Streptococcus pneumoniae. J. Bacteriol. 144, 457-459.

Song, W. Y., Kim, H. M., Hwang, C. Y., and Schaad, N. W. (2004). Detection of Acidovorax avenae ssp. avenae in rice seeds using BIO-PCR. J. Phytopathol. 152, 667-676. doi: 10.1111/j.1439-0434.2004.00914.x

Thompson, J. D., Higgins, D. G., and Gibson, T. J. (1994). ClustalW - improving the sensitivity of progressive multiple sequence alignment through sequence weighting, position-specific gap penalties and weight matrix choice. Nucleic Acids Res. 22, 4673-4680. doi: 10.1093/nar/22.22.4673

Tseng, H.-J., Mcewan, A. G., Apicella, M. A., and Jennings, M. P. (2003). OxyR acts as a repressor of catalase expression in Neisseria gonorrhoeae. Infect. Immun. 71, 550-556. doi: 10.1128/IAI.71.1.550-556.2003

Tu, W. Y., Pohl, S., Summpunn, P., Hering, S., Kerstan, S., and Harwood, C. R. (2012). Comparative analysis of the responses of related pathogenic and environmental bacteria to oxidative stress. Microbiology 158, 636-647. doi: 10.1099/mic.0.057000-0

van der Geize, R., Hessels, G., Van Gerwen, R., Vrijbloed, J., Van Der Meijden, P., and Dijkhuizen, L. (2000). Targeted disruption of the kstD gene encoding a 3-ketosteroid $\Delta^{1}$-dehydrogenase isoenzyme of Rhodococcus erythropolis strain SQ1. Appl. Environ. Microbiol. 66, 2029-2036. doi: 10.1128/AEM.66.5.20292036.2000

Wawrzynow, A., Banecki, B., and Zylicz, M. (2003). The Clp ATPases define a novel class of molecular chaperones. Mol. Microbiol. 21, 895-899. doi: 10.1046/j.13652958.1996.421404.x

Xie, G., Sun, X., and Mew, T. W. (1998). Characterization of Acidovorax avenae subsp. avenae from rice seeds. Zhongguo shuidao kexue 12, 165-171.

Xie, G. L., Zhang, G. Q., Liu, H., Lou, M. M., Tian, W. X., Li, B., et al. (2011). Genome sequence of the rice-pathogenic bacterium Acidovorax avenae subsp. avenae RS-1. J. Bacteriol. 193, 5013-5014. doi: 10.1128/JB.05594-11

Yu, Y., Streubel, J., Balzergue, S., Champion, A., Boch, J., Koebnik, R., et al. (2011). Colonization of rice leaf blades by an African strain of Xanthomonas oryzae pv. oryzae depends on a new TAL effector that induces the rice nodulin-3 Os11N3 gene. Mol. Plant Microbe Interact. 24, 1102-1113. doi: 10.1094/MPMI-1110-0254

Zheng, M., slund, F., and Storz, G. (1998). Activation of the OxyR transcription factor by reversible disulfide bond formation. Science $279,1718-1722$. doi: 10.1126/science.279.5357.1718

Zou, L. F., Li, Y. R., and Chen, G. Y. (2011). A non-marker mutagenesis strategy to generate poly-hrp gene mutants in the rice pathogen Xanthomonas oryzae pv. oryzicola. Agric. Sci. China 10, 1139-1150. doi: 10.1016/S1671-2927(11)60104-1

Zuber, P. (2009). Management of oxidative stress in Bacillus. Annu. Rev. Microbiol. 63, 575-597. doi: 10.1146/annurev.micro.091208.073241

Conflict of Interest Statement: The Review Editor Yuejin Hua declares that, despite being affiliated to the same institution as authors He Liu, Chun-Lan Yang, Meng-Yu Ge, Muhammad Ibrahim, Bin Li, Bo Zhu and Guan-Lin Xie, the review process was handled objectively and no conflict of interest exists. The authors declare that the research was conducted in the absence of any commercial or financial relationships that could be construed as a potential conflict of interest.

Received: 11 August 2014; accepted: 01 October 2014; published online: 21 October 2014.

Citation: Liu H, Yang C-L, Ge M-Y, Ibrahim M, Li B, Zhao W-J, Chen G-Y, Zhu B and Xie G-L (2014) Regulatory role of tetR gene in a novel gene cluster of Acidovorax avenae subsp. avenae RS-1 under oxidative stress. Front. Microbiol. 5:547. doi: 10.3389/fmicb.2014.00547

This article was submitted to Evolutionary and Genomic Microbiology, a section of the journal Frontiers in Microbiology.

Copyright (c) 2014 Liu, Yang, Ge, Ibrahim, Li, Zhao, Chen, Zhu and Xie. This is an open-access article distributed under the terms of the Creative Commons Attribution License (CC BY). The use, distribution or reproduction in other forums is permitted, provided the original author(s) or licensor are credited and that the original publication in this journal is cited, in accordance with accepted academic practice. No use, distribution or reproduction is permitted which does not comply with these terms. 